\title{
Behavioral Investigation of Reinforced Concrete T-Beams with Distributed Reinforcement in the Tension Flange
}

\author{
Rafaa M. Abbas ${ }^{1, a^{*}}$ and Wesal A. Fadala ${ }^{1, b}$ \\ ${ }^{1}$ Department of Civil engineering, University of Baghdad, Baghdad, Iraq. \\ adr.rafaa@coeng.uobaghdad.edu.iq, bw.ameen1101@coeng.uobaghdad.edu.iq
}

\begin{abstract}
Current design codes and specifications allow for part of the bonded flexure tension reinforcement to be distributed over an effective flange width when the T-beams' flanges are in tension. This study presents an experimental and numerical investigation on the reinforced concrete flanged section's flexural behavior when reinforcement in the tension flange is laterally distributed. To achieve the goals of the study, numerical analysis using the finite element method was conducted on discretized flanged beam models validated via experimentally tested T-beam specimen. Parametric study was performed to investigate the effect of different parameters on the T-beams flexural behavior. The study revealed that a significant reduction in the beam flexural strength with increasing deflection is encountered as a sizable percentage of reinforcement is distributed over the wider flange width. The study recommended that not more than $33 \%$ of the tension reinforcement may be distributed over an effective flange width not wider than $\ell \mathrm{n} / 10$. This result confirms and agrees well the ACI 318 limit on the effective width to be less than $\ell \mathrm{n} / 10$.
\end{abstract}

Keywords: Reinforced concrete; flanged section; T-beams; flexural reinforcement; finite element; flexure strength.

\section{Introduction}

T-beams and L-beams are the most commonly used flanged sections in conventional construction and moment-resisting frames. Because slabs are cast monolithically with the beam's web, additional stiffness or strength is added to the rectangular beam section from the slab's participation [1]. These beams are composed of two rectangular sections, the vertical web section and the horizontal flange. They are most efficient when compression exist in the flange part because a large area in the flange is available for compression. On the other hand, negative bending or tension in the flange in T-beams usually present in inverted beams cast monolithically with the slab or continuous RC Beams in the regions over support locations. Over the years, the flexure behavior of flanged RC beams was an extensive study area where many researchers studied load-deflection characteristics. As a result, different methods have been suggested to evaluate T-beams' flexure behavior [2]. Most recently, González and Ruiz [3] investigated the effect of the compression flange of slender T-beams without shear stirrups with emphasis on its influence on the critical shear crack behavior and the shear transfer actions. The proposed model results were compared with design codes and different shear design methods. The study showed that the effect of the flanges is accounted for by the proposed model. Cladera et al. [4] extended shear-flexural strength model previously developed by the authors to predict the strength of rectangular slender reinforced concrete beams with or without web reinforcement to account for the cases of T and I shape beams. Shaaban et al. [5] tested T-beam specimens of Normal Strength Concrete (NSC) and High Strength Concrete (HSC) to study their serviceability behavior. Comparison of the results of the proposed equations with tension reinforcement with the other studies revealed that current study equations have a close agreement with test results.

Al-Ansari [6] studied the reliability of reinforced concrete triangular and T-beams using the reliability index approach. Their behavior was also investigated experimentally and analytically. The study has shown that the experimental results were smaller than those obtained numerically. This indicated the reliability of the finite element results. Al-Hassani et al. [7] tested hybrid T- beams casted using normal concrete in the flange with reactive powder concrete in the web. The flexural 
behavior was evaluated, and the testing results showed that using hybrid concrete has improved the strength of hybrid T-section beams greatly. As the slab and the beams are casted monolithically, it is permitted to include the contribution of the slab with the strength of the beam. The portion of the slab contributes to beam strength called the effective flange [8]. Due shearing deformation of the flange, which relieves the more remote elements of some compressive stress, i.e., shear-lag phenomenon. The variable compressive stresses that acting on the overall width can be replaced by an equivalent uniformly distributed compressive force that working on an effective width adopted by design procedures $[9,10]$. A flange's effective width is the width of a theoretical flange that has uniform compressive stress across its width with the compressive stress resultant comparable to that of the loaded edge of the real flange.

Although a large number of studies have been carried out on reinforced concrete T-beams in the past years, it is infrequent to find research works on the negative moment regions of continuous $\mathrm{T}$ beams. Regarding the effect of lateral distribution of the tension rebars in the tension flange, no work has been reported in the literature. In this context, this paper aims to address the practical problem that is faced in usual practice when bonded tension reinforcement is distributed in the tension flanges of T-beams as permitted by ACI 318-19 design code [11] to secure the outer portions of the flange against excessive flexure cracks. The flexural behavior will be investigated, and the effect of tension reinforcement distribution is highlighted and discussed.

\section{Research Methodology}

To achieve this study's goals, full-scale reinforced concrete T-beam models representative of typical slab-beam system in buildings were analyzed. The idealized T-beams with the effective flanges were represented and discretized by a 3-D finite element model using Abaqus CAE software. To this end, the developed finite element model has been validated based on comparison with the results from testing a scale-down reinforced concrete T-beam specimen prepared in this study. After that, a numerical parametric study was carried out to evaluate the impact of the distributed rebars percentage, arrangement, and the parameters considered on the adopted T-beam models' flexural behavior. The study results for the flexure behavior of the investigated T-beam models due to reinforcement distribution were presented, evaluated, and discussed.

\section{T-Beam Model}

To investigate the problem under consideration numerically, a proposed model of an interior reinforced concrete $\mathrm{T}$-beam representative of typical full scale reinforced concrete slab-beam system in common construction was adopted in the current study as shown in Figure 1. The selected T-beam model have a clear span of $\mathrm{L}_{\mathrm{n}}=5 \mathrm{~m}$, effective flange width $\mathrm{b}_{\mathrm{f}}=1.50 \mathrm{~m}$, total depth of the beam $\mathrm{h}=$ $0.50 \mathrm{~m}$, and slab thickness $\mathrm{h}_{\mathrm{f}}=0.150 \mathrm{~m}$. It is reinforced with $6 \# 20$ steel rebars in the web at the flange section. Web or shear reinforcement comprised of \#12@150 mm c/c stirrups. Flexure and shear reinforcement was selected to ensure tension control flexure failure under applied load. Cylinder concrete compressive strength of $30 \mathrm{MPa}$ and yield stress of $420 \mathrm{MPa}$ were assumed for the concrete section's material properties and the reinforcement bars, respectively.

The indicated tension reinforcement located in the beam flange to simulate tension in the flange for the case of negative moment at the support regions for continuous beams or positive moment reinforcement for the inverted beam where the flange located beneath the beam stem. The selected effective flange width of $1.50 \mathrm{~m}$ was calculated following the limitation stipulated in Table 6.3.2.1 of the ACI318M-2019 [11] for the indicated slab model dimensions. 


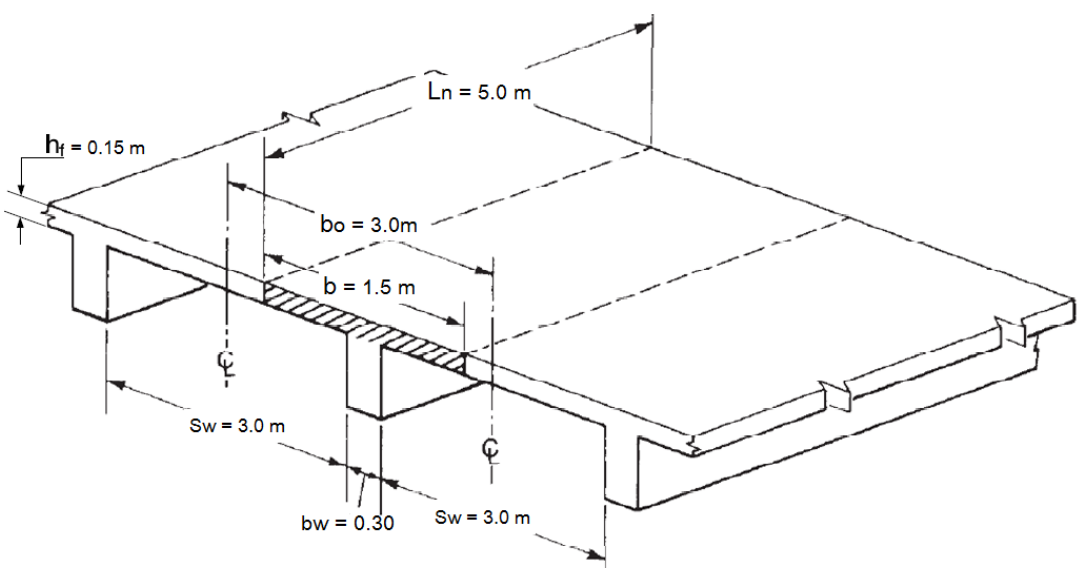

(A) Slab-Beam Model

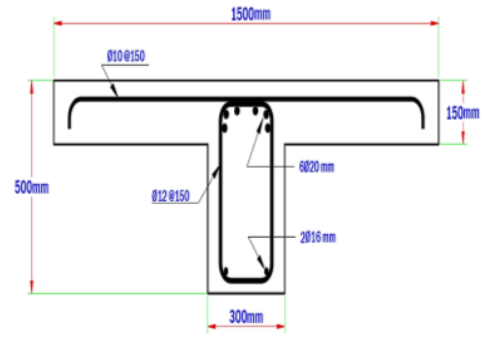

(B) T-Beam Section

Figure 1 T-beam model.

Finally, the beam model will be analyzed numerically as a simply supported beam with the flange section located beneath the beam web as shown in Figure 2 to simulate the case of tension in the flange as adopted in the experimental testing program used to validate the finite element model results. Beam reinforcement flexure and shear reinforcement were selected to ensure flexure failure due to monotonic static concentrate mid-span load.

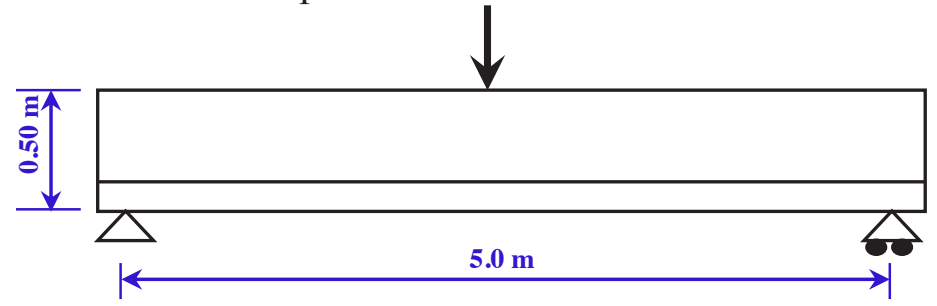

Figure 2. T-beam schematic representation.

\section{Finite Element Model}

The finite element method is considered the most efficient and versatile approximate method of analysis for any structural problem as compared with the more exact, costly, and time-consuming experimental testing technique. Therefore, a finite element model has been developed to investigate reinforced concrete T-beam's flexural behavior in this study. This section presents the finite element modeling for the investigated beam shown in Figure 2. The FE modeling for any structural problem must include all structural aspects required for the determination of the load-deflection curve and give essential information regarding the stiffness and strength of the structure. These include; the topology of the structure containing spans, cross-sections of the members, boundary conditions, and the material properties and the acting loads.

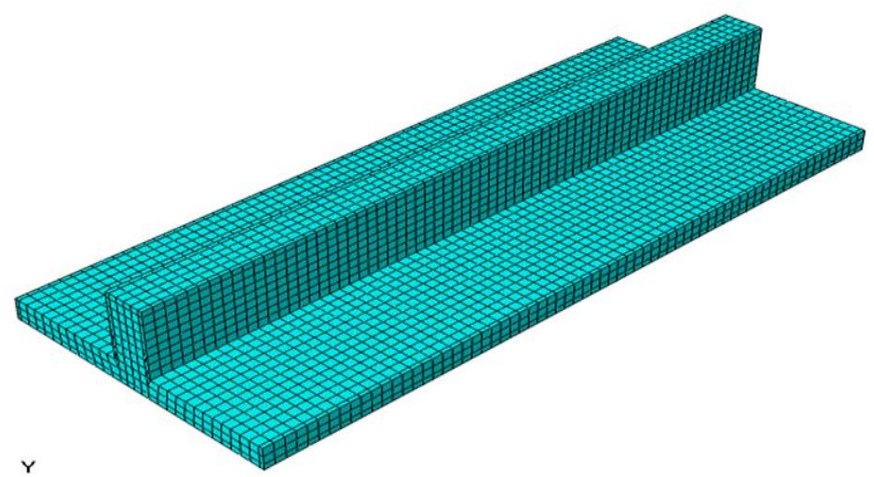

Figure 3. Discretized T-beam finite element model.

Three-dimensional finite element models have been prepared and calibrated using the results of the conducted experimental work. Abaqus CAE 6.19 software has been used in the modeling process. 
Figure 3 shows the structural model for the T-beam model that was adopted in the numerical analysis. In the part module, ABAQUS features can be used to simulate different structural geometry. To represent the concrete section, a solid 8-node brick element (C3D8R) was used to simulate the concrete section in the beam web and flange. On the other hand, a three-dimensional wire truss element simulates the longitudinal and stirrup reinforcements. Nonlinear finite element analysis was performed to simulate the real behavior of concrete beams. The plasticity aspects of the concrete material Concrete Damaged Plasticity, CDP, have been used. Part modules must be connected to achieve effective assembly of the different parts by using the interaction module. For the reinforcement rebars, embedded constraints have been adopted to ensure the perfect bond with the surrounding concrete. Part instants must be connected together to operate in a tied form.

\section{Validation of the FE Model}

To justify the applicability of the developed FE model presented in the aforementioned section, the experimental testing program was conducted in this study to validate the adopted FE model. To this end, a new finite element model to simulate the scaled-down tested beam was performed using the same Abaqus modulus, elements, and interaction constraints presented previously. The experimental work involved casting, and testing of one simply supported scaled-down RC T-beam. Fig. 4 shows the details of the tested specimen.
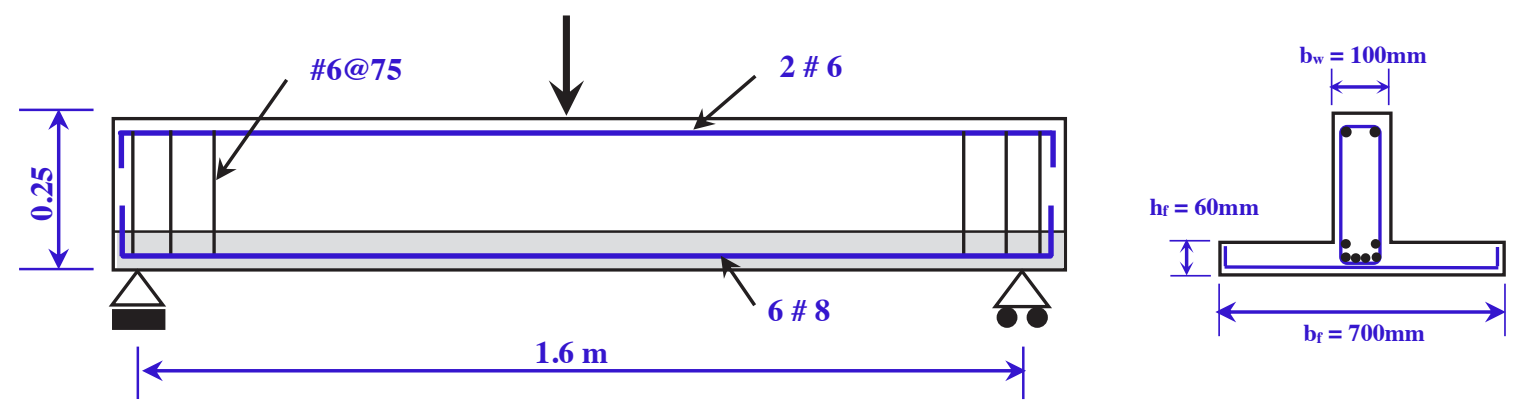

Figure 4. Tested T-beam (TB700) specimen details.

The tested beam represents 1:3 reduced or scaled-down RC T-beam specimen with a shear span/depth ratio $(\mathrm{a} / \mathrm{d})$ of 3.5 . The tested beam with a total span of $1700 \mathrm{~mm}$ was casted using $25 \mathrm{MPa}$ concrete compressive strength material. Beam reinforcement were $6 \# 8 \mathrm{~mm}$ rebars as the main tension reinforcement, 2\#6mm as nominal rebars on the compression side, and \#6mm@75 mm c/c rebars as shear reinforcement. The reinforcement and the beam details were selected to attain tension control failure according to ACI 318 [11]. Finally, the testing setup presented in Figure 4 is to simulate the problem examined in this study of flexure tension, cracking, and tension stiffening in the flange of a RC T-beam. Figure 5 shows the testing setup conducted in the structural lab at the University of Baghdad, whereas Figure 6 shows the cracking pattern and the deformed T-beam at failure under mid-span concentrated load.

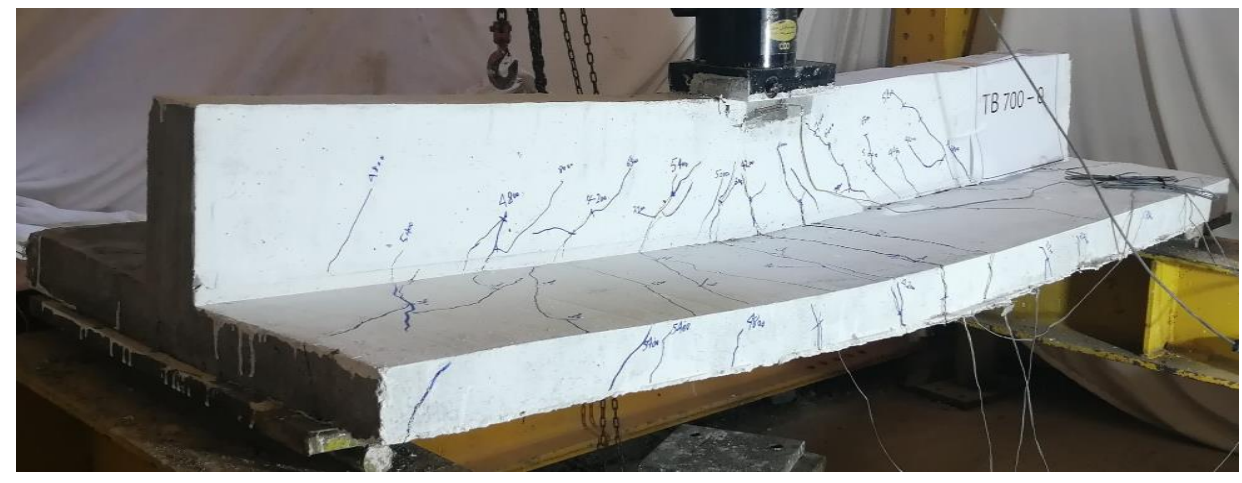

Figure 5. Testing setup for T-beam (TB700) specimen. 


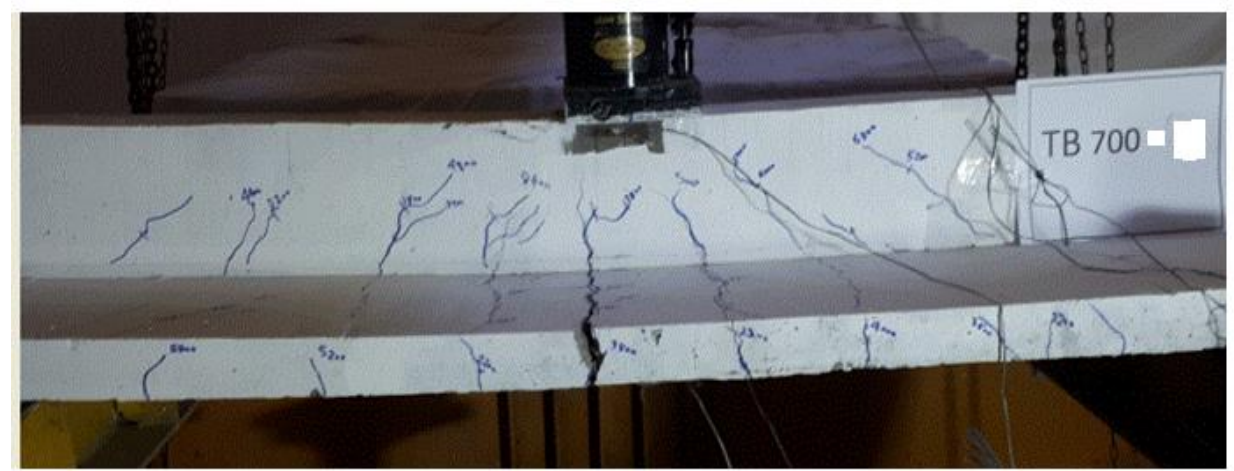

Figure 6. Deflection and cracking at failure for T-beam (TB700) specimen.

The developed finite element model for the scaled-down tested RC T-beam was analyzed under monotonic mid-span concentrated force until failure to achieve the validation task's goal. The loaddeflection response at different load increments was documented and compiled for comparison with the experimental test results. For the experimental work, applied load values at each increment were recorded with the corresponding deflection using a load cell and electronic dial gauge at beam midspan. The efficiency of the developed FE model is presented by the comparison shown in Figure 7. This figure shows the load-deflection curve at mid-span for the numerical and the experimental results for TB700 specimen.

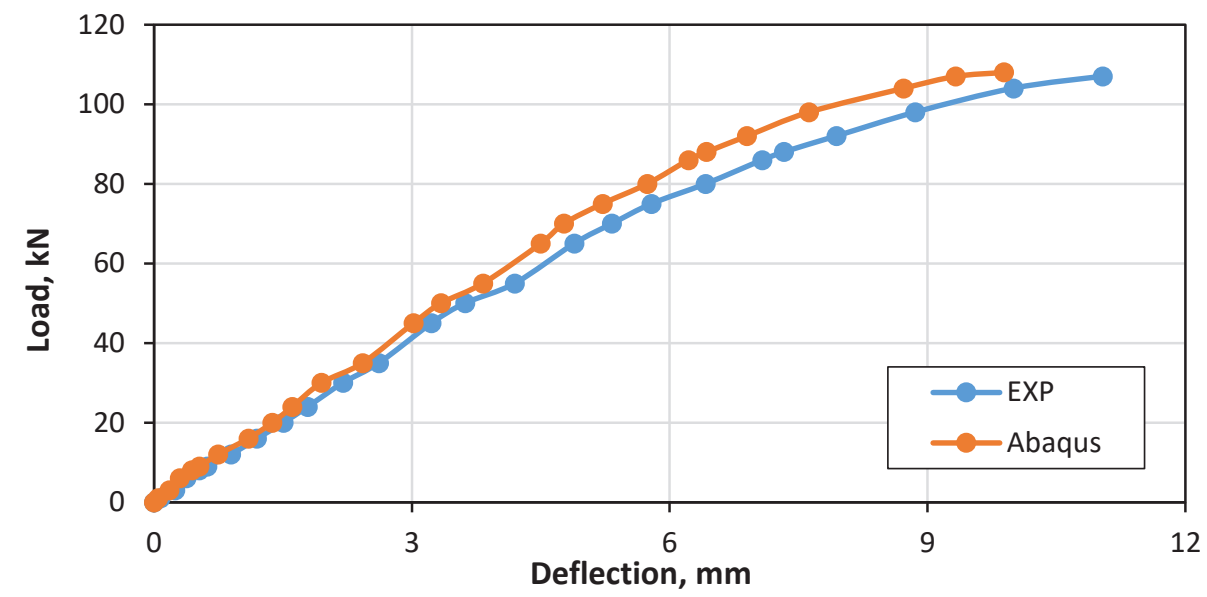

Figure 7. Experimental and finite element load-deflection curves for TB700 specimen.

The results shown in Figure 7 indicated close agreement between the load-deflection curve for the numerical model and that for the experimental specimen and that the values of the deflection and the ultimate load compare well for both numerical and experimental models. The difference percentage for the ultimate load and the deflection values compiled in Table 1 revealed that the finite element model could provide reliable analysis results comparable to the experimental ones.

Table 1. Comparison of experimental and FE results for TB700 specimen.

\begin{tabular}{|c|c|c|c|c|c|c|}
\hline \multirow{2}{*}{$\begin{array}{l}\text { Beam } \\
\text { designation }\end{array}$} & \multicolumn{2}{|c|}{ Finite Element results } & \multicolumn{2}{c|}{ Experimental results } & \multicolumn{2}{c|}{ Validation ratio } \\
\cline { 2 - 7 } & $\begin{array}{c}\mathbf{P}_{\mathbf{u}, \mathbf{F E}} \\
(\mathbf{k N})\end{array}$ & $\Delta_{\mathrm{FE}}(\mathbf{m m})$ & $\begin{array}{c}\mathbf{P}_{\mathbf{u}, \mathbf{E X P}} \\
(\mathbf{k N})\end{array}$ & $\Delta_{\mathbf{E X P}}(\mathbf{m m})$ & $\begin{array}{c}\text { Strength } \\
\text { ratio }\end{array}$ & $\begin{array}{c}\text { Deflection } \\
\text { ratio }\end{array}$ \\
\hline $\mathrm{TB} 700$ & 108 & 9.89 & 107 & 11.4 & $0.93 \%$ & $13.2 \%$ \\
\hline
\end{tabular}

These results indicated that the deflection values obtained experimentally were larger than those using the finite element model, demonstrating that the experimental specimen possesses higher ductility at failure than did the FE model for the same T-beam. 


\section{Parametric Study and Results Discussion}

In this section, the calibrated finite element model was used to conduct an extensive numerical study in order to investigate the structural behavior of RC T-beam when part of the bonded tension reinforcement is distributed in the tension flange. In this study, the effect of three parameters was studied; effective flange thickness, concrete compressive strength, and total beam depth. Three different values for the effective flange thickness $b_{f}(100,150$, and $200 \mathrm{~mm})$, three different values for the concrete compressive strength $(20,30$, and $40 \mathrm{MPa})$, and three different values for the beam depth $\mathrm{h}(400,500$, and $600 \mathrm{~mm})$ have been considered. Each time one parameter was considered, all the other mechanical properties of the model were kept constant at the average value for each parameter. In order to keep consistent with the ACI 318 code recommendations, two additional aspects must be justified; the part or percentage of the web reinforcement to be distributed and the effective flange width over which the part of the reinforcement is allowed to be distributed. The beam models compiled in Table 2 have been investigated numerically using the developed finite element analysis. The beam designation adopted was as follow:

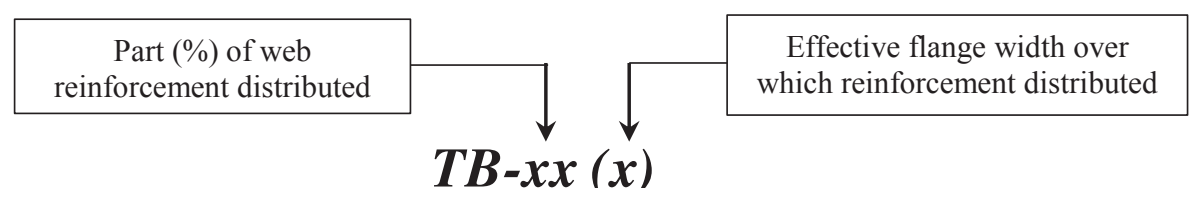

Table 2. Beam model properties used for the parametric study.

\begin{tabular}{|c|c|c|c|c|c|c|}
\hline \multirow[b]{2}{*}{$\begin{array}{l}\text { Parameter } \\
\text { considered }\end{array}$} & \multicolumn{6}{|c|}{ Beam Properties } \\
\hline & $\begin{array}{c}\text { Beam } \\
\text { designation }\end{array}$ & $\begin{array}{l}\text { Length } \\
(\mathrm{mm})\end{array}$ & $\begin{array}{l}\text { Flange width } \\
\quad(\mathrm{mm})\end{array}$ & $\begin{array}{l}\text { Beam depth } \\
\text { (h) } \mathrm{mm}\end{array}$ & $\begin{array}{l}\text { Compressive } \\
\text { Strength } f c^{\prime} \\
\text { (MPa) }\end{array}$ & $\mathbf{h}_{\mathbf{f}}(\mathbf{m m})$ \\
\hline \multirow{5}{*}{$\begin{array}{c}\text { Flange thickness } \\
\left(h_{f}\right) \\
(100,150,200) \mathrm{mm}\end{array}$} & TB-0 & 5000 & 1500 & 500 & 30 & - \\
\hline & TB-33(1) & 5000 & 1500 & 500 & 30 & - \\
\hline & TB-33(2) & 5000 & 1500 & 500 & 30 & - \\
\hline & TB-66(1) & 5000 & 1500 & 500 & 30 & - \\
\hline & TB-66(2) & 5000 & 1500 & 500 & 30 & - \\
\hline \multirow{5}{*}{ 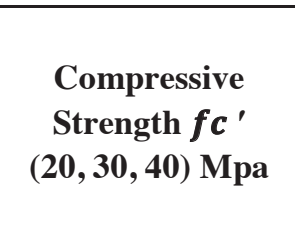 } & TB-0 & 5000 & 1500 & 500 & - & 150 \\
\hline & TB-33(1) & 5000 & 1500 & 500 & - & 150 \\
\hline & TB-33(2) & 5000 & 1500 & 500 & - & 150 \\
\hline & TB-66(1) & 5000 & 1500 & 500 & - & 150 \\
\hline & TB-66(2) & 5000 & 1500 & 500 & - & 150 \\
\hline \multirow{5}{*}{$\begin{array}{c}\text { Beam depth }(\text { h) } \\
(400,500,600) \\
\text { mm }\end{array}$} & TB-0 & 5000 & 1500 & - & 30 & 150 \\
\hline & TB-33(1) & 5000 & 1500 & - & 30 & 150 \\
\hline & TB-33(2) & 5000 & 1500 & - & 30 & 150 \\
\hline & TB-66(1) & 5000 & 1500 & - & 30 & 150 \\
\hline & TB-66(2) & 5000 & 1500 & - & 30 & 150 \\
\hline
\end{tabular}

In the beam designation, the implemented part or percentage of the bonded reinforcement distributed was $0 \%, 33 \%$, and $66 \%$ of the total tension reinforcement. Whereas the effective flange width over which the reinforcement to be distributed was taken; (1) reinforcement distributed over width not wider than $\ell \mathrm{n} / 10$, and (2) reinforcement distributed over width wider than $\ell \mathrm{n} / 10$. The adopted flange width limitation for reinforcement distribution was as recommended by the ACI 318 . Figure 8 shows the details for the T-beam cross-section and reinforcement distribution as given in Table 2. It is important to note that the beam models were analyzed as simply supported beams with the flange located beneath the beam web, as shown in Fig. 2, to simulate the case of tension in the flange. 


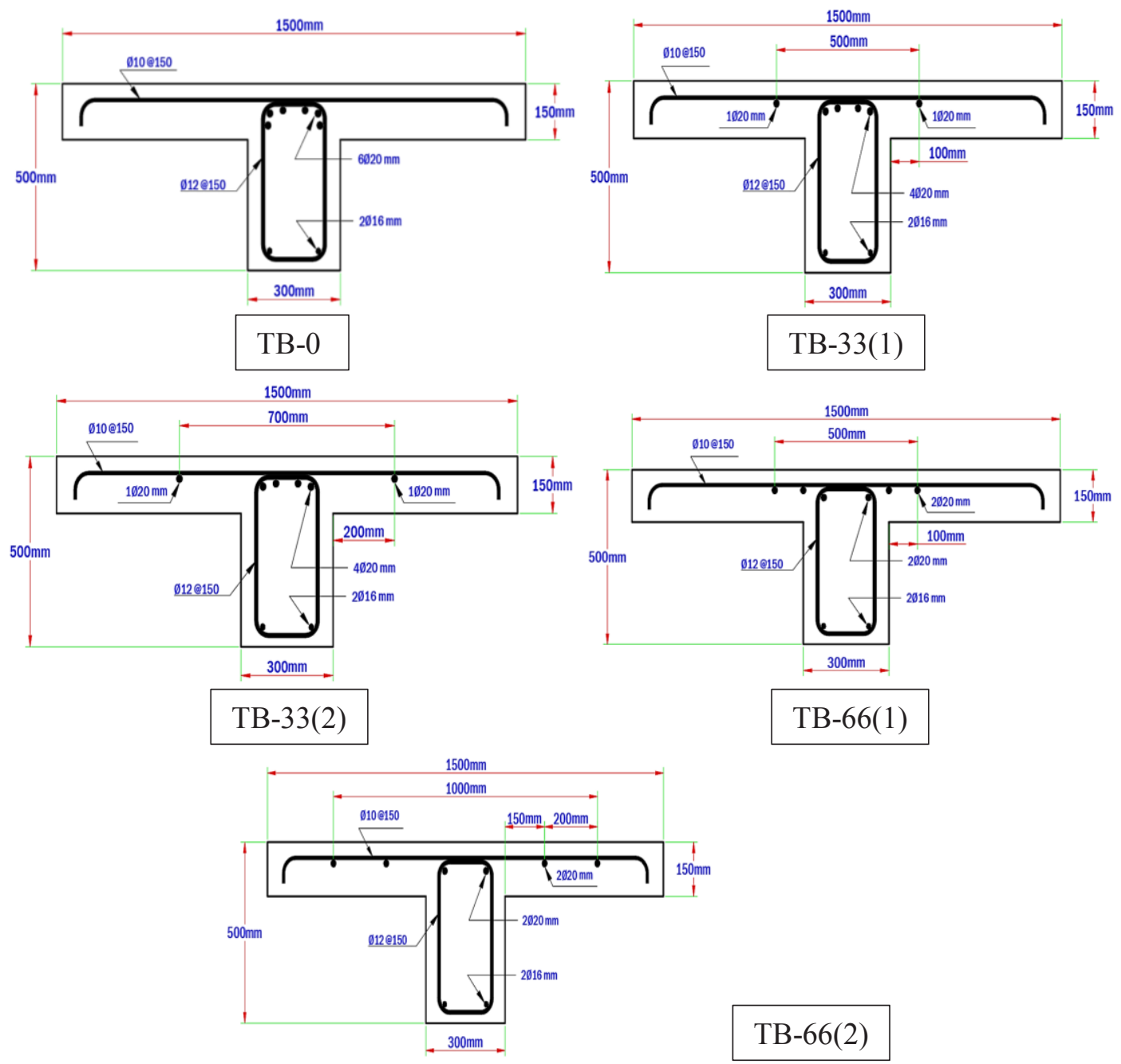

Figure 8. T-beam cross-section and reinforcement distribution details.

Figures 9, 10, and 11 show the load-deflection curves for the investigated beams listed in Table 2. On the other hand, Tables 3, 4, and 5 show the variation percentages in the ultimate load and the deflections of the T-beam models due to the effect of the parameters considered and the distribution for part of the flexure reinforcement in the selected effective flange width. It is noted that the RC Tbeam "TB-0" is regarded as the reference beam in the current study.
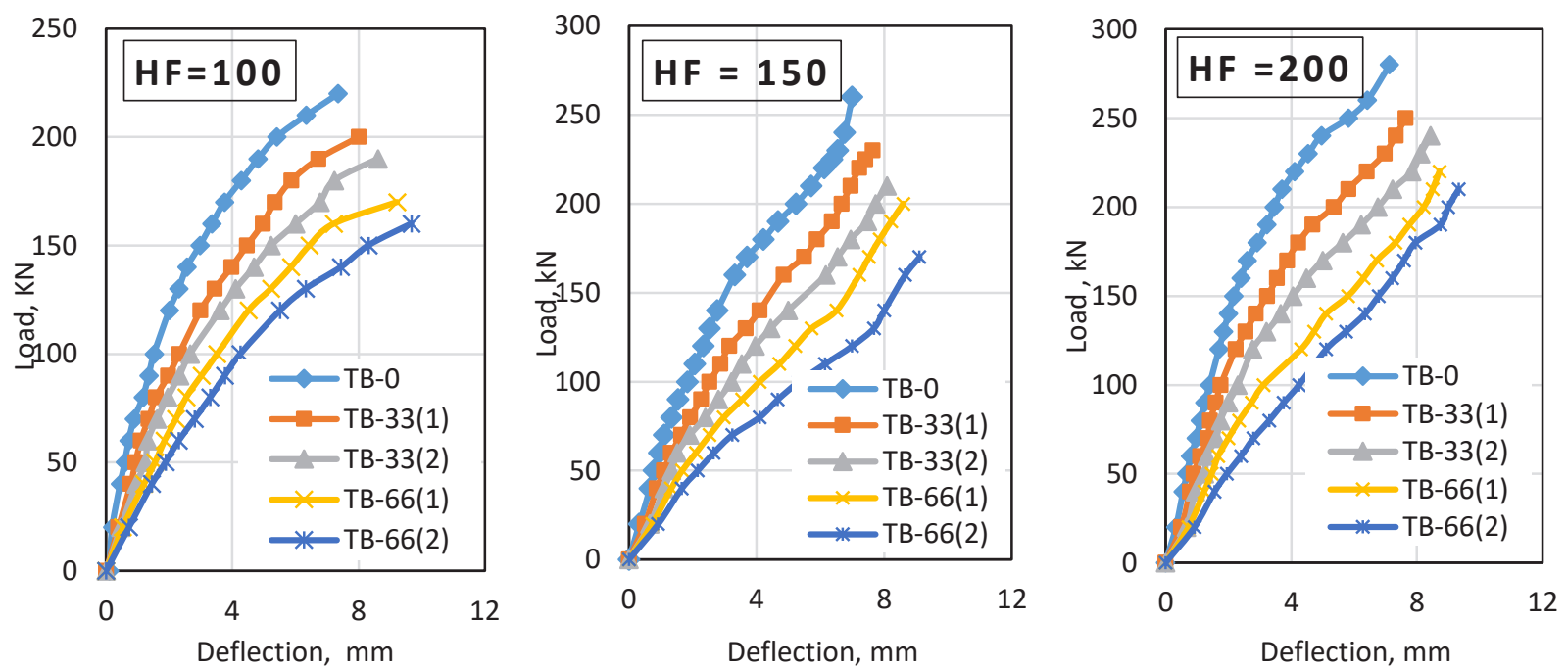

Figure 9. Load-deflection curves for different flange thickness values. 

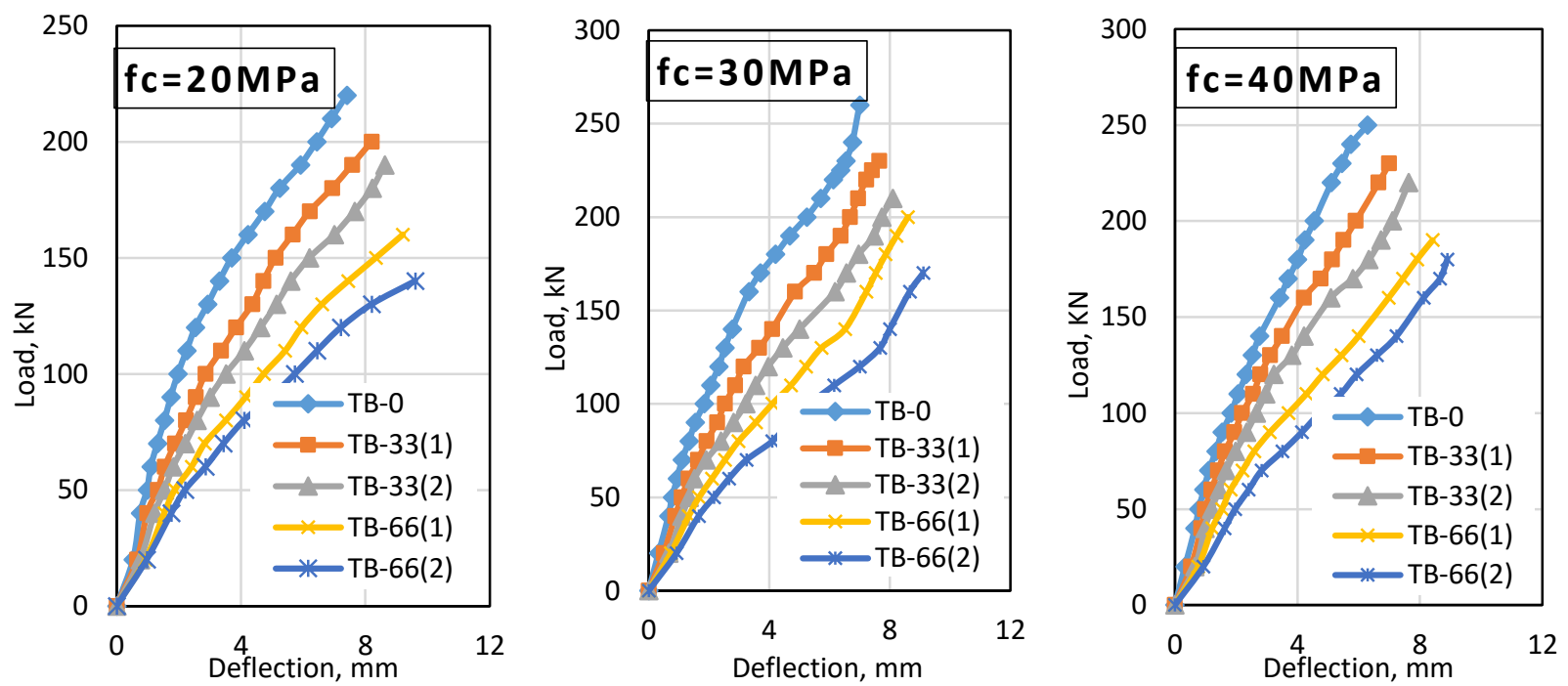

Figure 10. Load-deflection curves for different concrete compressive strength values.
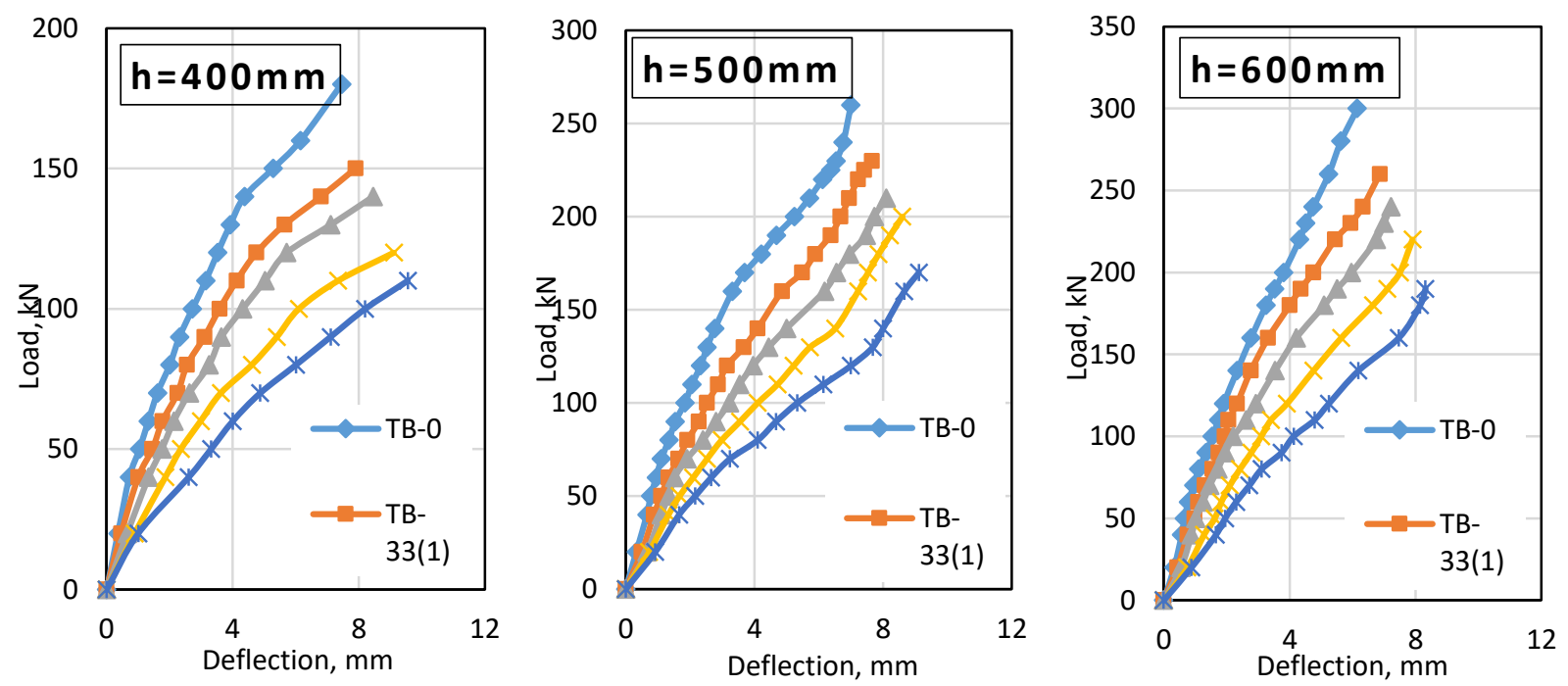

Figure 11. Load-deflection curves for different beam depth values.

Table 3. Variation percentages in the flexure behavior due to the flange thickness effect.

\begin{tabular}{|c|c|c|c|c|c|}
\hline \multirow{2}{*}{\multicolumn{2}{|c|}{ Beam designation }} & \multicolumn{2}{|c|}{ FE analysis results } & \multicolumn{2}{|c|}{ Variation ratio } \\
\hline & & \multirow{2}{*}{$\begin{array}{c}\begin{array}{c}\text { Ultimate load } \\
\mathbf{P}_{\mathbf{u}},(\mathbf{k N})\end{array} \\
220\end{array}$} & \multirow{2}{*}{ 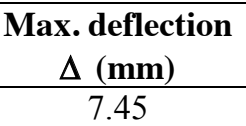 } & \multirow{2}{*}{$\begin{array}{c}\text { Strength } \\
\text { ratio (\%) } \\
----\end{array}$} & \multirow{2}{*}{$\begin{array}{c}\text { Deflection ratio } \\
(\%)\end{array}$} \\
\hline \multirow{5}{*}{$\begin{array}{l}\text { Flange thickness } \\
\quad=100 \mathrm{~mm}\end{array}$} & TB-0 & & & & \\
\hline & TB-33(1) & 200 & 8 & -9.1 & 7.4 \\
\hline & TB-33(2) & 190 & 8.61 & -13.6 & 15.6 \\
\hline & TB-66(1) & 170 & 9.22 & -22.7 & 23.7 \\
\hline & TB-66(2) & 150 & 9.67 & -31.8 & 29.8 \\
\hline \multirow{5}{*}{$\begin{array}{l}\text { Flange thickness } \\
\quad=150 \mathrm{~mm}\end{array}$} & TB-0 & 250 & 7 & $-\overline{-}_{---}$ & ---- \\
\hline & TB-33(1) & 210 & 7.56 & -16.0 & 6.6 \\
\hline & TB-33(2) & 200 & 8.23 & -20.0 & 17.5 \\
\hline & TB-66(1) & 190 & 8.6 & -24.0 & 22.8 \\
\hline & TB-66(2) & 180 & 9.11 & -28.0 & 30.1 \\
\hline \multirow{5}{*}{$\begin{array}{l}\text { Flange thickness } \\
\quad=200 \mathrm{~mm}\end{array}$} & TB-0 & 280 & 6.54 & --- & ---- \\
\hline & TB-33(1) & 250 & 7.1 & -10.7 & 8.5 \\
\hline & TB-33(2) & 240 & 7.58 & -14.3 & 15.9 \\
\hline & TB-66(1) & 220 & 8.05 & -21.4 & 23.1 \\
\hline & TB-66(2) & 210 & 8.64 & -25.0 & 32.1 \\
\hline
\end{tabular}


Table 4 Variation percentages in the flexure behavior due to concrete strength effect.

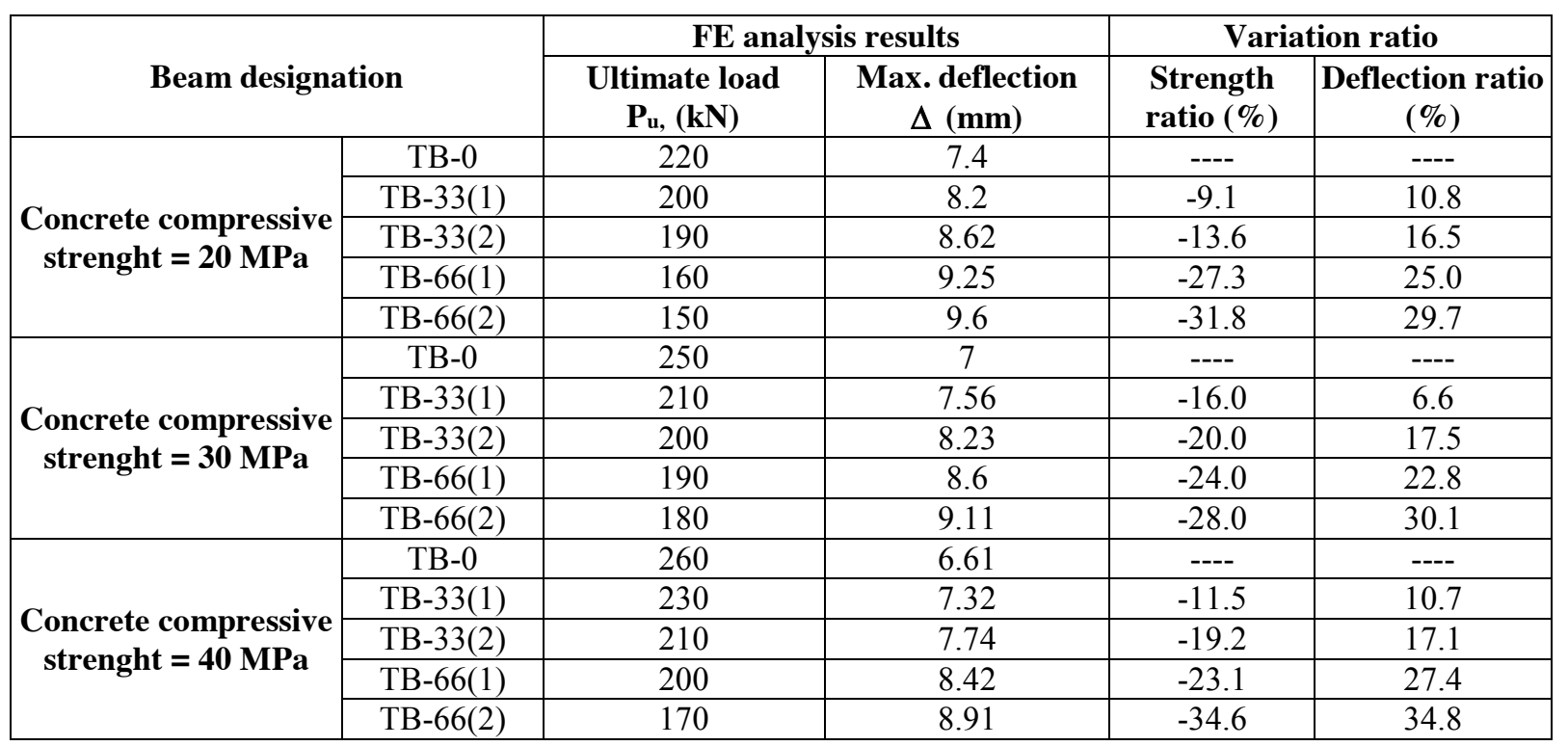

Table 5. Variation percentages in the flexure behavior due to beam depth effect.

\begin{tabular}{|c|c|c|c|c|c|}
\hline \multirow{2}{*}{\multicolumn{2}{|c|}{ Beam designation }} & \multicolumn{2}{|c|}{ FE analysis results } & \multicolumn{2}{|c|}{ Variation ratio } \\
\hline & & \multirow{2}{*}{$\begin{array}{c}\begin{array}{c}\text { Ultimate load } \\
\mathbf{P}_{\mathbf{u},(\mathbf{k N})}\end{array} \\
180 \\
\end{array}$} & \multirow{2}{*}{$\begin{array}{c}\text { Max. deflection } \\
\Delta(\mathbf{m m})\end{array}$} & \multirow{2}{*}{$\begin{array}{c}\begin{array}{l}\text { Strength } \\
\text { ratio }(\%)\end{array} \\
---\end{array}$} & \multirow{2}{*}{\begin{tabular}{|c|}
$\begin{array}{c}\text { Deflection ratio } \\
(\%)\end{array}$ \\
---- \\
\end{tabular}} \\
\hline \multirow{5}{*}{$\begin{array}{c}\text { Beam depth }= \\
400 \mathrm{~mm}\end{array}$} & TB-0 & & & & \\
\hline & TB-33(1) & 150 & 7.89 & -16.6 & 5.3 \\
\hline & TB-33(2) & 140 & 8.45 & -22.2 & 12.0 \\
\hline & TB-66(1) & 120 & 9.11 & -33.3 & 21.3 \\
\hline & TB-66(2) & 110 & 9.5 & -38.9 & 26.7 \\
\hline \multirow{5}{*}{$\begin{array}{c}\text { Beam depth }= \\
500 \mathrm{~mm}\end{array}$} & TB-0 & 250 & 7 & ---- & ---- \\
\hline & TB-33(1) & 210 & 7.56 & -16.0 & 6.6 \\
\hline & TB-33(2) & 200 & 8.23 & -20.0 & 17.5 \\
\hline & TB-66(1) & 190 & 8.6 & -24.0 & 22.8 \\
\hline & TB-66(2) & 180 & 9.11 & -28.0 & 30.1 \\
\hline \multirow{5}{*}{$\begin{array}{c}\text { Beam depth }= \\
600 \mathrm{~mm}\end{array}$} & TB-0 & 300 & 6.15 & ---- & $\begin{array}{ll}--- \\
\end{array}$ \\
\hline & TB-33(1) & 260 & 6.87 & -13.3 & 11.7 \\
\hline & TB-33(2) & 240 & 7.22 & -20.0 & 17.4 \\
\hline & TB-66(1) & 220 & 7.91 & -26.7 & 19.1 \\
\hline & TB-66(2) & 190 & 8.35 & -36.7 & 35.8 \\
\hline
\end{tabular}

In the following, Table 6 presents a summary for the ranges of the minimum and maximum variation percentages in the ultimate load and maximum deflection values resulted from the effect of reinforcement distribution and for the different parameters considered. The minimum range presented is for T-beam model "TB-33(1)", while the maximum range presented is for T-beam model "TB66(2)". Results presented in Table 6 revealed that a maximum reduction in the ultimate load capacity of about 7\% and an increase in the maximum deflection of about $5 \%$ had been observed due to the effect of the flange thickness or the concrete compressive strength. At the same time, a value of about $10 \%$ was indicated due to the effect of the beam depth for the decrease and increase in the ultimate load capacity and in the maximum deflection, respectively.

Table 7 summarizes the average values for the percentages decrease or increase in the ultimate load capacity and the maximum deflection, respectively, due to the combined effect of the reinforcement distributed, effective width for reinforcement distribution, and the three parameters considered. Results compiled in Table 7 showed that the reinforcement and the effective width were the most influential factors affecting T-beams' flexure behavior with distributed reinforcement. 
Table 6. Ranges for the variation percentages in the flexure behavior.

\begin{tabular}{|c|c|c|c|c|}
\hline \multirow{2}{*}{ Parameters considered } & \multicolumn{2}{|c|}{ Reduction in the ultimate load } & \multicolumn{2}{c|}{ Increas in the max. deflection } \\
\cline { 2 - 5 } & $\begin{array}{c}\text { Min. variation } \\
\text { percentages }\end{array}$ & $\begin{array}{c}\text { Max. variation } \\
\text { percentages }\end{array}$ & $\begin{array}{c}\text { Min. variation } \\
\text { percentages }\end{array}$ & $\begin{array}{c}\text { Max. variation } \\
\text { percentages }\end{array}$ \\
\hline $\begin{array}{c}\text { Flange thickness }\left(\mathrm{h}_{\mathrm{f}}\right) \\
(100,150,200) \mathrm{mm}\end{array}$ & $9.1-16.0$ & $25.0-31.8$ & $6.6-8.5$ & $29.8-32.1$ \\
\hline $\begin{array}{c}\text { Compressive Strength } \boldsymbol{f} \boldsymbol{c}^{\prime} \\
(20,30,40) \mathrm{MPa}\end{array}$ & $9.0-16.0$ & $28.0-34.6$ & $6.6-10.8$ & $29.7-34.8$ \\
\hline $\begin{array}{c}\text { Beam depth }(\mathrm{h}) \\
(400,500,600) \mathrm{mm}\end{array}$ & $13.3-16.6$ & $28.0-38.9$ & $5.3-11.7$ & $26.7-35.8$ \\
\hline
\end{tabular}

Table 7. Summary of the average variation percentages in the flexure behavior.

\begin{tabular}{|c|c|c|}
\hline Parameters considered & $\begin{array}{c}\text { Reduction in the beam } \\
\text { ultimate load, } \%\end{array}$ & $\begin{array}{c}\text { Increase in the beam max. } \\
\text { deflection, } \%\end{array}$ \\
\hline $\begin{array}{c}\text { Reinforcement distributed, } 33 \% \\
\text { Effective width, } \leq \ell \mathrm{n} / 10\end{array}$ & 12 & 8.7 \\
\hline $\begin{array}{c}\text { Reinforcement distributed, } 33 \% \\
\text { Effective width, }>\ell \mathrm{n} / 10\end{array}$ & 17.9 & 16.5 \\
\hline $\begin{array}{c}\text { Reinforcement distributed, } 66 \% \\
\text { Effective width, } \leq \ell \mathrm{n} / 10\end{array}$ & 28.0 & 23.2 \\
\hline $\begin{array}{c}\text { Reinforcement distributed, } 66 \% \\
\text { Effective width, }>\ell \mathrm{n} / 10\end{array}$ & 32.0 & 30.8 \\
\hline
\end{tabular}

\section{Conclusions}

In this study, the flexural strength and the deflection of reinforced concrete T-beam with the flange in tension have been investigated when part of the bonded flexural reinforcement was distributed over an effective flange width. Experimental scaled-down T-beam specimen was tested to validate the developed FE beam model adopted for the numerical investigation carried out in this study. The parametric study results showed that the ultimate load reduced and the maximum deflection decreased when the tension reinforcement distributed and that flange thickness, concrete compressive strength, and the beam depth have a slight effect on the various percentages of the beam flexure behavior.

On the other hand, the study revealed that the distributed reinforcement and the effective width were the most effective factors affecting the flexure behavior of T-beams. As the part (percentage) of the distributed reinforcement increased and located over wider width, a significant reduction in the beam ultimate load with increasing deflection was encountered. The study showed that $33 \%$ of distributed reinforcement over effective width $\leq \ell \mathrm{n} / 10$ resulted in $12 \%$ reduction in beam flexure strength with $8.7 \%$ increase in the beam max. deflection. Abrupt reduction in beam strength and increased deflection were observed for $66 \%$ of distributed reinforcement over an effective width $>$ $\ell \mathrm{n} / 10$. The study recommended that a percentage of not more than $33 \%$ of the tension reinforcement be distributed over effective flange width not wider than $\ell \mathrm{n} / 10$ to limit the beam flexure strength reduction. Finally, the research agrees with the ACI 318 recommendation to provide additional reinforcement in the flange's outer portions, as these reinforcement help maintain the beam flexural strength.

\section{Acknowledgment}

The authors wish to thank the Department of Civil Engineering at the University of Baghdad for their valuable support to complete this work. The authors gratefully acknowledge the support received from the head and the staff of the Department. 


\section{References}

[1] Darwin, D., Dolan, C.W. and Nilson, A.H., 2016. Design of concrete structures. New York, NY, USA:: McGraw-Hill Education.

[2] Kalkan, İ., 2013. Deflection prediction for reinforced concrete beams through different effective moment of inertia expressions. Uluslararası Mühendislik Araştırma ve Geliştirme Dergisi, 5(1), pp.1-1.

[3] Ribas González, C.R. and Fernández Ruiz, M., 2017. Influence of flanges on the shear-carrying capacity of reinforced concrete beams without web reinforcement. Structural concrete, 18(5), pp.720-732.

[4] Cladera, A., Marí, A., Ribas, C., Bairán, J. and Oller, E., 2015. Predicting the shear-flexural strength of slender reinforced concrete T and I shaped beams. Engineering Structures, 101, pp.386-398.

[5] Shaaban, I.G., Saidani, M., Nuruddin, M.F., Malkawi, A. and Mustafa, T., 2018. Serviceability behavior of normal and high-strength reinforced concrete t-beams. European Journal of materials Science and Engineering.

[6] Al-Ansari, M.S., 2015. Reliability and flexural behavior of triangular and T-reinforced concrete beams. International Journal of Advanced Structural Engineering (IJASE), 7(4), pp.377-386.

[7] Al-Hassani, H.M., Al-Kafaji, J.M. and Ismael, A.L.M.A., 2015. Flexural behavior of hybrid Tee Beams (Containing Reactive Powder Concrete and Normal Strength Concrete). Journal of Engineering and Sustainable Development, 19(2).

[8] McCormac, J.C. and Brown, R.H., 2015. Design of reinforced concrete. John Wiley \& Sons.

[9] Shakir, H.J., 2015. Finite Element Investigation on Shear Lag in Composite Concrete-Steel Beams with Web Openings. Journal of Engineering, 21(3), pp.11-33.

[10] Qin, X.X., Liu, H.B., Wang, S.J. and Yan, Z.H., 2015. Symplectic analysis of the shear lag phenomenon in a T-beam. Journal of Engineering Mechanics, 141(5), p.04014157.

[11] ACI 318M-19, 2019. Building Code Requirements for Structural Concrete and Commentary, an ACI Standard, American Concrete Institution. 